\title{
Palvelutyöntekijästä ammattiyhdistysaktiiviksi
}

\section{Luottamusmiesten urakerronta matalapalkkaisella yksityisellä palvelusektorilla}

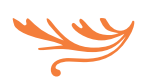

Luottamusmiehet kokevat ammattiyhdistysuran merkitysten kietoutuvan työntekijöiden edustajana toimimisen, oman osaamisen ja asiantuntijuuden

rakentumisen sekä ajankäyttömahdollisuuksien tasapainottamisen ympärille. Asia käy ilmi Palvelualojen ammattiliiton (PAM) luottamusmiesten uratarinoista. Aktiivisimmilla luottamusmiehillä ay-toiminta on merkittävä osa elämää, ja siinä on havaittavissa urakehityksen piirteitä.

\section{$\boldsymbol{y}$}

TYÖURA YMMÄRRETÄÄN YLEENSä ylöspäin etenevänä kehityksenä organisaatioiden hierarkioissa portaalta toiselle, ja se on yhdistetty erityisesti korkeasti koulutettuihin ja johtavassa asemassa oleviin työntekijöihin (Kirton 2006, 47; Hennequin 2007, 565-568).

Keskustelu urasta on ollut leimallisesti keskiluokkaista. Vähäisten koulutusvaatimusten matalapalkkaiset palvelualat ovat tarjonneet työntekijöille verrattain heikosti uraetenemisen mahdollisuuksia (Lindsay 2005). Työtä tehdään aloilla usein tiukkojen tuotantovaatimusten ja ulkoisen kontrollin alaisena (Ott 2016). Työntekijöiden vaihtuvuus on yleistä, ja monia palvelutöitä on pidetty niin kutsuttuina läpikulkualoina, joilla työskennellään opintojen lomassa tai samaan aikaan muuta työtä etsien. Yksityiset palvelualat ovat toimineet kuitenkin merkittävänä työllistäjänä, ja niiden roolia on pidetty suomalaisten työmarkkinoiden kannalta tärkeänä myös tulevaisuudessa (esim. TEM 2015).

Työntekijöitä edustavien luottamusmiesten toimintaa ei ole yleensä totuttu ajattelemaan tietoisena uravalintana, joka tarjoaisi erityisiä urakehityksen mahdollisuuksia. Yksi selitys tälle on se, että luottamusmiehet hoitavat tehtäväänsä pääsääntöisesti muun työnsä ohessa. Työntekijöiden edustajien 
AmMATtiYHDistystoimintaA

ON PIDETTY PERINTEISESTI

MIEHISEN $\dddot{A}$ ELÄMÄNALUEENA.

tehtäviin on liitetty myös kielteisiä piirteitä, kuten tehtävien korkea kuormittavuus ja kiittämätön luonne (esim. Lawrence 1994; Bradley 1999, 175; Kainulainen 2018).

Luottamusmiestoiminnan on lisäksi osoitettu olevan sukupuolittunutta (esim. Bradley 1999; Kainulainen \& Saari 2014; Saari 2016; Kainulainen 2018; Kainulainen 2020), ja ammattiyhdistystoimintaa on pidetty perinteisesti miehisenä elämänalueena (esim. Bradley 1999; Julkunen 2008; Ledwith 2012). Suomalaisessa ammattiyhdistysterminologiassa on käytetty sukupuolittunutta luottamusmiehen käsitettä, mitä on selitetty sillä, että sukupuolineutraalilla luottamushenkilön käsitteellä tarkoitetaan luottamusmiesten lisäksi muita luottamustehtäviä, kuten työsuojeluvaltuutetun tehtävää.

Naisten ammattiyhdistysuria tarkastelevassa tutkimuksessa on tuotu esille, miten ay-urat toimivat sekä vaihtoehtoisena että rinnakkaisena naisten muille urille, sekä miten ammattiyhdistysuraa tekevien naisten on usein tasapainoteltava erilaisten urien, kuten pienten lasten vanhempana toimimisen ja työuran, välillä (Kirton 2006). Tutkimuksissa on kuitenkin harvoin tarkasteltu sitä, millaisia kehitysvaiheita ammattiliittojen luottamusmiestehtäviin liittyy ja millaista ammatillista kasvua ne mahdollistavat.

Tarkastelen tässä artikkelissa Palvelualojen ammattiliiton (PAM) luottamusmiestehtävään liittyvää urakerrontaa osana luottamusmiesten elämänkulkua. Naisvaltainen PAM on lähes 217000 jäsenellään Suomen suurin ammattiliitto (SAK 2019). Se edustaa matalapalkkaisia yksityisiä palvelualoja, kuten kauppojen myyjiä, hotelli- ja ravintola-alan työntekijöitä sekä siivoojia.

Olen kiinnostunut siitä, millaista urakerrontaa luottamusmiestoiminnan eri vaiheista voidaan erottaa sekä millaisena ay-aktiivin uralle päätyminen, ja sillä eteneminen näyttäytyvät erityisesti subjektiivisen urakäsityksen näkökulmasta. 'Subjektiivisella uralla' tarkoitan luottamusmiesten ay-aktiivisuuteen liittämiä merkityksiä, heidän käsityksiään omasta ay-toiminnan historiastaan sekä ay-uraa koskevia tulevaisuuden odotuksia (ks. esim. Collin \& Watts 1996, 391-393). Lisäksi kysyn, miten sukupuoli merkityksellistyy luottamusmiesten uraa koskevissa käsityksissä, mielikuvissa ja itsemäärittelyissä.

Tutkimustehtävääni ohjaa pohdinta siitä, millaisia henkilökohtaisia etenemis- ja kehittymismahdollisuuksia luottamusmiestoiminta tarjoaa matalasti kouluttautuneille työntekijöille ja missä määrin usein väliaikaiseksi jäävästä luottamusmiestehtävästä voidaan puhua urana. Urakerronnan kautta on mahdollista jäljittää luottamusmiesten ay-aktiivisuutta elämänkulkuun kiinnittyvänä, käynnissä olevana prosessina. Uriin keskittyminen avaa samalla suomalaisessa työelämän suhteiden tutkimuksessa vähälle huomiolle jääneen näkökulman siihen, millä tavoin ay-toiminta on ruohonjuuritasolla muutoksessa ja millaisia haasteita nämä muutokset aiheuttavat ay-liikkeelle.

\section{AMMATTIYHDISTYSAKTIIVISUUS \\ MATALAPALKKAISELLA YKSITYISELLÄ PALVELUSEKTORILLA}

Ay-aktiivisuutta on perinteisesti pidetty työväenluokkaisena, teollisena ja maskuliinisena toimintana (esim. Lawrence 1994; Bradley 1999; Julkunen 2008, 67; Ledwith 2012). Suomessa naiset ovat kuitenkin miehiä useammin ammattiliiton jäseniä, mikä on johtunut erityisesti naisvaltaisen julkisen sektorin verrattain vahvasta järjestäytymisen perinteestä. Naisvaltaisia yksityisiä palvelualoja voidaan pitää sen sijaan poikkeuksellisen heikosti järjestäytyneinä. Edunvalvonnan piirissä olevien järjestäytymisaste oli vuonna 2017 julkisilla palvelualoilla 73 prosenttia, kun yksityisillä palvelualoilla järjestäytyneitä oli 48 prosenttia (Ahtiainen 2019).

Verrattain heikon järjestäytymisen ohella yksityisiä palvelualoja on pidetty ay-toiminnan kannalta haasteellisina esimerkiksi pienten työpaikkojen suuren osuuden, osa-aikatyön yleisyyden sekä nuorten ja maahanmuuttajataustaisten työntekijöiden suuren määrän takia (esim. Dølvik \& Waddington 
TYÖURAT RAKENTUVAT

KATKOSTEN, MUUTOSTEN

JA VALINTOJEN

MONINAISUUDESSA.

2002). Yksityisten palvelualojen työntekijöillä on lisäksi ollut muita aloja harvemmin luottamusmies tukenaan, mitä selittää osaltaan pienten työpaikkojen suuri määrä (ks. SAK 2004). Palvelualojen erityispiirteet ovat näkyneet alojen ay-aktiivisuudessa, sillä työntekijöiden lyhyttä työhistoriaa ja ammattijärjestön jäsenyyttä on pidetty syynä vähäisemmälle ay-osallistumiselle (Bradley 1999, 166; Ahtiainen 2015, 36-37).

Aiemmassa ay-aktiiveja käsittelevässä tutkimuksissa on tuotu esille, miten työn ja muun elämän yhdistäminen on yksi olennainen ay-aktiivisuutta vaikeuttava tekijä (esim. Lawrence 1994; Kirton 2006). Haasteet ovat olleet sukupuolittuneita, sillä perheen ja työn yhteensovittamisen ongelma on koskenut erityisesti naisia (Lawrence 1994; Kirton 2006; Kainulainen 2020). Matalapalkkaisella ja yksityisellä palvelusektorilla työntekijöiden ay-toimintaa hankaloittaa sekin, että työtä tehdään usein niin kutsuttujen normaalityöaikojen ulkopuolella iltaisin, öisin ja viikonloppuisin (Kainulainen 2020). Työaikojen asettuminen eri vuorokauden aikoihin ja viikonlopulle on yleistä erityisesti sellaisilla naisvaltaisilla aloilla, joilla on paljon osa-aikaisia työntekijöitä, kuten vähittäiskaupassa, majoitus- ja ravitsemustoiminnassa sekä kiinteistöpalveluissa (Kauhanen 2016).

Tutkimuksen kohteena olevan PAMin jäsenistä 76 prosenttia on naisia. Ammattiliiton 1623 luottamusmiehestä naisia on 59 prosenttia, ja 55 päätoimisesta pääluottamusmiehestä vähän yli puolet (PAM 2019b). Naisten pienempi osuus luottamusmiehissä kuin jäsenissä selittyy osaltaan sillä, että naisvaltaisilla aloilla on enemmän pieniä työpaikkoja kuin miesvaltaisilla aloilla. Jäsenistön sukupuolijakaumaan verrattuna miehet ovat yliedustettuina myös ammattiliiton hallinnossa, sillä PAMin hallituksen 15 varsinaisesta jäsenestä naisia oli vuonna 2019 noin 60 prosenttia (2019c).

Aiemmassa ammattiliittojen sukupuolirakenteita käsittelevässä tutkimuksessa on nostettu esille se, miten naisten kasvanut osuus työvoimassa ei ole kuitenkaan vaikuttanut ammattiliittojen ylempien portaiden miehisiin rakenteisiin (Ledwith 2012). Suomessa miehiset valtarakenteet tulevat esille esimerkiksi siinä, miten kaikkien kolmen työntekijöiden keskusjärjestön, Suomen Ammattiliittojen Keskusjärjestön (SAK), STTK:n ja AKAVAn, puheenjohtaja on mies, vaikka ammatillisesti järjestäytyneistä vuoden 2017 tietojen (Ahtiainen 2019) mukaan 56 prosenttia oli naisia.

PAMin sisällä tasa-arvokysymyksistä koskeva keskustelu nousi pinnalle artikkelin kirjoittamisen aikaan kesäkuussa 2019 järjestetyssä liittokokouksessa, jossa hyväksyttiin esitys työntekijöitä ja luottamushenkilöitä koskevasta sukupuoliarvioinnista. PAMin toimitsijan henkilökohtaisen tiedonannon mukaan sen yhtenä tarkoituksena on selvittää ammattiliiton eri asemien sukupuolijakaumia, mistä voidaan päätellä, että tehtävien jakautuminen sukupuolen perusteella kiinnostaa myös ammattiliitossa.

\section{URAKERRONTA JA SUKUPUOLISTAVAT KÄYTÄNNÖT}

Työntekijöiden urat rakentuvat jälkiteollisessa työssä katkosten, muutosten ja valintojen moninaisuudessa, eivät välttämättä selkeän yhden polun kautta. Sen vuoksi ura-käsitteen käyttöä on uratutkimuksessa laajennettu muillekin elämänalueille. Urateorioita tarkastelleet Sherry E. Sullivan ja Yehuda Baruch $(2009,1543)$ ovat tiivistäneet uratutkimuksen pohjalta 'uran' tarkoittavan "yksilöiden työtä tai muita merkityksellisiä kokemuksia organisaatioissa tai niiden ulkopuolella, mitkä muodostavat erityisen kokonaisuuden yksilön elämänkulussa”. Näin märirteltynä 'ura' tulisi ymmärtää ennen kaikkea käynnissä olevana prosessina. Uran käsitteen avulla on ollut mahdollista jäsentää ja selkeyttää ihmisten elämäntilanteiden moninaisuutta ja elämänpiirien eriytymistä (Komulainen \& Sinisalo 2006, 150). 
ORGANISAATIOIDEN

K ̈̈YT̈̈NTEET

\section{TULKITAAN MONESTI \\ SUKUPUOLINEUTRAALEIKSI.}

Aiemmissa ay-aktiiveja käsittelevässä tutkimuksessa sukupuolta on pidetty yhteiskuntaluokan ohella yhtenä keskeisenä ay-aktiivien elämänkulkua jäsentävänä yhteiskunnallisena erona (Lawrence 1994; Kirton 2006; Moore 2011). Naisten ay-uria Isossa-Britanniassa tarkastellut Gill Kirton (2006) esittää, että naisten ay-toimintaan osallistumisen ymmärtämiseksi on olennaista huomioida ura laajana, horisontaalisena ja moninaisena käsitteenä. Työurien tutkimuksessa on myös yleisemmin tuotu esille, että on tärkeää kiinnittää huomioida sekä uran objektiivisiin että subjektiivisiin puoliin (Collin \& Watts 1996, 393-395; Komulainen \& Sinisalo 2006, 151).

'Objektiivisella uralla' tarkoitetaan uratutkimuksessa uraa määrittäviä instituutioita (Arthur \& Rousseau 1996, 7), ja käsitteellä on viitattu muodollisiin titteleihin ja työtehtävien jatkumoon (Collin \& Watts 1996, 392). Lähestyn luottamusmiesten urakerrontaa erityisesti subjektiivisen urakäsityksen näkökulmasta, jolloin kyse on muodollisten ja selkeästi rajattujen asemien sijaan yksilöiden omalle uralleen antamista merkityksistä (mt.). Analyysissani huomioin lisäksi ay-uran objektiivisen puolen, jolla tarkoitan luottamusmiestehtävään kiinnittyviä muodollisia positioita, kuten ammattiliiton hallinnollisia luottamusasemia, sekä luottamusmiestoiminnan sisäisiä hierarkioita toimipaikkakohtaisista luottamusmiehistä päätoimisiin pääluottamusmiehiin.

Työelämän suhteiden tutkimuksessa on 2000-luvun vaihteen jälkeen korostettu sukupuolen ja muiden erojen merkitystä työntekijöiden kokemusten ja intressien tarkastelemisessa (esim. Wajcman 2000; Ledwith 2012, Kainulainen \& Saari 2014; Saari 2016; Kainulainen 2018; Rubery \& Hebson 2018; Kainulainen 2020). On muun muassa esitetty palkattoman työn nostamista taloudellisen tuotannon rinnalle. Lisäksi on korostettu, miten sukupuolta tu- lisi lähestyä jatkuvasti tuotettavana eikä vain työpaikoilla ilmenevänä erona. (Rubery \& Hebson 2018.) Suomalaista työelämää sukupuolen näkökulmasta tarkasteleva Päivi Korvajärvi (2004, 23-24) tiivistää sukupuolen tekemisen neljään keskenään risteävään lähestymistapaan, joissa sukupuolen nähdään rakentuvan esimerkiksi ihmisten välisissä vuorovaikutustilanteissa, toiminnan ja yhteiskunnan rakenteiden välisissä käytännöissä, symboleissa ja mielikuvissa, sekä sukupuolen esityksissä.

Lähestyn sukupuolen käsitettä työelämän sukupuolistavien käytäntöjen näkökulmasta. Sukupuolen, yhteiskuntaluokan ja etnisyyden välisiä suhteita tarkastelevan amerikkalaisen sosiologin Joan Ackerin (1997) mukaan sukupuolistavien käytäntöjen käsite kiinnittää huomion siihen, miten sukupuolittuneita rakenteita tuotetaan ihmisten jokapäiväisessä arkisessa toiminnassa. Käsitteen (Acker 1990a; 1997) lähtökohtana on pyrkimys haastaa organisaatioihin liitettyä oletusta niiden sukupuolineutraaliudesta. Sukupuolistavat käytännöt voidaan ymmärtää kysymyksenä sukupuolen kytkeytymisestä yhteiskunnallisiin rakenteisiin ja kiinnittymisenä valtaan (Korvajärvi \& Kinnunen 1996, 233). Ne pitävät organisaatioissa yllä sukupuolten eriarvoisuutta (Acker 1997), mutta niiden kautta on myös mahdollista tuoda esille naisten tekemän työn arvostusta ja sitä kautta vahvistaa naisten asemaa yhteiskunnassa (Korvajärvi \& Kinnunen 1996, 233).

Sukupuolistavat käytännöt voivat olla näkyviä tai näkymättömiä, mutta niiden piiloon jäämistä lisää se, että organisaatioiden käytänteet tulkitaan monesti sukupuolineutraaleiksi (Acker 1997). Päivi Korvajärvi ja Merja Kinnunen (1996, 234-240) määrittävät Ackerin (esim. 1990b) teoretisointiin tukeutuen sukupuolistavia käytäntöjä koskeviksi tarkastelunäkökulmiksi sukupuolistavat mielikuvat, itsemäärittelyt ja vuorovaikutuksen.

Tarkoitan 'sukupuolistavilla käytännöillä' luottamusmiesten urakerronnassa esiintyviä merkityksiä, mielikuvia ja itsemäärittelyjä, jotka tuottavat ay-toiminnan sukupuolittuneita järjestyksiä. Aiemmissa artikkeleissani olen analysoinut tutkimuksen aineistoa edunvalvonnan sukupuolistavien käytäntöjen (Kainulainen \& Saari 2014), tunteiden ja työntekijöiden 


\section{KERRONNALLISUUS TOIMII}

\section{ANALYYSINI J ̈̈SENT ÄMIST $\ddot{A}$ \\ SUUNTAAVANA V ̈̈LINEEN ̈̈.}

äänen välisten suhteiden (Kainulainen 2018) sekä työn prekarisaation ja luottamusmiesten toimijuuden näkökulmasta (2020). Nyt suuntaan analyysini luottamusmiesten ammattiyhdistysuriin.

\section{AINEISTO JA METODOLOGIA}

Artikkelini aineistona toimivat 24 luottamusmiehen teemahaastattelua sekä viidessä PAMin järjestämässä luottamusmieskoulutuksessa tuotettu kenttäaineisto. Aineisto on osa vuosina 2009-2014 tuottamaani monipaikkaista etnografista aineistokokonaisuutta, jonka keräämistä on ohjannut kiinnostukseni luottamusmiesten arjen kokemuksiin ja ruohonjuuritason ay-aktiivisuuteen. Aineiston rajaaminen perustui siihen, että yksilöhaastatteluiden kautta pääsin käsiksi luottamusmiesten omakohtaiseen urakerrontaan ja eri vaiheissa oleville luottamusmiehille suunnatut koulutukset tarjosivat mahdollisuuden tarkastella näitä vaiheita usean luottamusmiehen näkökulmasta samanaikaisesti ${ }^{1}$. Kiinnostusta ihmisten elettyihin kokemuksiin tietyssä ryhmässä tai kulttuurissa on pidetty tutkijan osallistuvan lähestymistavan ohella yhtenä etnografisen tutkimuksen keskeisenä piirteenä (esim. Angrosino 2007).

'Monipaikkaisuudella' tarkoitetaan etnografisessa tutkimuksessa sitä, että aineisto tuotetaan yhden selkeärajaisen kentän sijaan monella eri kentällä (Marcus 1995). Yhden pitkäkestoisen kenttätyön sijaan tutkija tuottaa aineistokokonaisuuden erilaisissa vaihtuvissa tiloissa tapahtuvissa kenttävierailuissa (Hämeenaho \& Koskinen-Koivisto 2014, 12-13).

Haastatelluista luottamusmiehistä 15 oli naisia ja yhdeksän miehiä. Toteutin useimmat haastattelut luottamusmieskursseilla havainnoimisen yhteydessä; lisäksi haastattelin luottamusmiehiä PAMin ja yliopiston tiloissa sekä yhden luottamusmiehen työpaikalla. Haastateltujen ammattialoista yleisin oli kauppa $(\mathrm{N}=10)$ ja toiseksi yleisin majoitus- ja ravitsemustoiminta $(\mathrm{N}=6)$. Muut alat olivat suuruusjärjestyksessä varastoala, kiinteistöpalvelu, puhelinpalvelu ja vartiointi.

Kursseilla tuotettu havainnointiaineisto koostuu kahdesta luottamusmiesten peruskurssista yhteensä kahdeksalta havainnointipäivältä - olin toisen koulutuksen jälkimmäiseltä kahden päivän osalta pois - kahdesta luottamusmiesten jatkokurssista yhteensä 20 havainnointipäivältä ja yhdestä päätoimisille luottamushenkilöille suunnatusta täydennyskoulutuksesta yhteensä kahdelta havainnointipäivältä. Luottamusmiesten perus- ja jatkokursseille osallistui noin 20 luottamusmiestä ja aktiiveille suunnattuun koulutukseen noin 70 luottamusmiestä ja työsuojeluvaltuutettua.

Haastattelut kestivät vajaasta puolesta tunnista reiluun puoleentoista tuntiin. Hyödynsin niissä etukäteen laatimaani kysymyslistaa. En kuitenkaan kysynyt kaikilta haastateltavilta samoja kysymyksiä, sillä kysymykset elivät osana etnografista tutkimusprosessia ja muuta aineiston tuottamista (ks. Huttunen \& Homanen 2017). Kysymysten vaihtelua selitti osaltaan aineiston tuottamisen pitkä kesto. Haastattelut noudattavat ennalta mietittyjen kysymysten ja teemojen suhteen puolistrukturoitua teemahaastattelua (ks. esim. Hyvärinen 2017), mutta kysymysten vaihtelun ja kentän vaikutuksen suhteen niissä on myös etnografisen haastattelun piirteitä (Huttunen \& Homanen 2017, 144-149). Annoin ennen haastatteluja miettimistäni kysymyksistä huolimatta haastateltaville mahdollisuuden kuljettaa keskustelua heidän haluamiinsa suuntiin.

Aineiston analyysissä hyödynnän kerronnallisen tutkimuksen tarjoamaa viitekehystä. Sitä on pidetty hyödyllisenä myös etnografiassa, koska kertomukset avaavat näkökulman kertojien käsityksiin niistä merkityksistä, joita he liittävät elämänsä, ympäristönsä ja yhteisöjensä kannalta tärkeisiin tapahtumiin (Cortazzi 2001, 384). Kerronnallisessa tutkimuksessa kertomuksia ja kertomista voidaan käyttää niin tiedon rakentajana kuin sen välittäjänä. Tutkimuksen materiaali koostuu kertomuksista, mutta itse tutkimuskin voidaan ymmärtää kertomukseksi. (Heikkinen 2010.) 
Kerronnallisuuden kautta lähestyn luottamusmiesten ammattiyhdistystoimintaa prosessina, jolla on erilaisia vaiheita ja joka tarjoaa erilaisia henkilökohtaisen kehittymisen mahdollisuuksia. Toisin sanoen kerronnallisuus toimii analyysini jäsentämistä suuntaavana välineenä, eikä pyrkimykseni ole luokitella aineistoa esimerkiksi erilaisiin kertomustyyppeihin (ks. Heikkinen 2010). Analyysissa keskityn merkityksiin, jotka koskevat luottamusmiestehtävässä aloittamista ja siinä etenemistä sekä avaan tehtävän mahdolliseen lopettamiseen liittyviä pohdintoja. Lähtökohtanani on tavoittaa ruohonjuuritason ay-toimintaa koskevien kokemusten ja merkitysten moninaisuus.

Aloitin analyysin konstruoimalla erilaiset luottamusmiesuran vaiheet, jotka muodostavat ay-aktiiviksi kehittymisen prosessin rungon. Tukeuduin tässä erityisesti luottamusmieskoulutuksissa tuotettuun aineistoon. Sen jälkeen luin haastatteluaineistoa etsimällä siitä erilaisia tarinallisia episodeja, jotka tuovat esille luottamusmiesten uraan liittämiä merkityksiä. Tarkoitukseni oli rakentaa analyysini tarinamuotoon, jossa on alkuvaihe, keskikohta ja loppu. Kysyin kaikissa haastatteluissa, pitävätkö luottamusmiehet itseään ay-aktiivina sekä miten he määrittävät ayaktiivin. Analyysissa erittelin aluksi näitä ay-aktiivin määritelmiä ja sitä, miten haastateltavat määrittävät itseänsä suhteessa niihin. Tämän jälkeen analysoin luottamusmiesmiesten aineistossa rakentuvia urakehityksen kuvauksia, joita luokittelin ay-uran vaiheiden näkökulmasta.

Analyysi rakentui kahdessa osassa. Ensimmäisessä vaiheessa hyödynsin luottamusmiesten haastatteluaineistoa $(\mathrm{N}=24)$ ja kursseilla tuotettua havainnointiaineistoa $(\mathrm{N}=5)$ kokonaisvaltaisesti. Tämän jälkeen rajasin haastateltavia valikoivalla otannalla keskittymällä niihin luottamusmiehiin, jotka vastasivat olevansa ay-aktiiveja tai näkivät itsensä ainakin osittain sellaisena. Heitä oli haastatelluista yhdeksän naista ja seitsemän miestä. Valtaosa heistä oli suurten yritysten päätoimisia luottamusmiehiä $(\mathrm{N}=9)$.

Analyysin rungon muodostaa pääluottamusmiehenä toimivan Ailan tarina, jonka olen konstruoinut kertomuksen muotoon haastattelun pohjalta. Valitsin Ailan tarinan analyysia kuljettavaksi ja jäsentäväksi kertomukseksi, koska hänen haastattelussaan on paljon sellaisia piirteitä, jotka tulivat esille muidenkin luottamusmiesten haastatteluissa. Olen poistanut aineistositaateista turhaa toistoa, täytesanoja ja käsitellyt kieliasua helpommin luettavaksi. Tarvittaessa olen muokannut haastattelusitaatteja haastateltavien anonymiteetin turvaamiseksi.

\section{Aloituskertomus - luottamusmieheksi}

Aila aloitti myyjän työt ruokakaupassa teini-ikäisenä ja päätyi työskentelemään myyjän ammatissa koko työuransa ajan ennen kuin tuli valituksi päätoimiseksi luottamusmieheksi. Kaupan alalle hän oli päätynyt monien muiden työntekijöiden tavoin ilman sen tarkempaa suunnitelmallisuutta. Ailan kaltaiset ajautumisen kokemukset toistuivat aineistossa laajemminkin (haastattelut 1, 3, 5-14, 19-20, 22-24). Työt oli aloitettu nuorena, ja töitä oli etsitty esimerkiksi työttömäksi jäämisen, alan vaihtamisen tai opinnoista valmistumisen takia.

Aila lopetti lyhyen kertomuksensa työurastaan toteamalla: "[--] nuorena kävin kaupassa, mutta sitten tein lapsia ja olin kotona välillä, että tämä on tämä minun elämäntarina.” Kokemukset perheestä työuraa jäsentävänä tekijänä toistuivat muidenkin päätoimisina luottamusmiehinä toimivien naisten urakerronnassa. Hoitovapaat pilkkoivat työuraa, ja lapsen kanssa kotona oleminen oli saattanut vaikuttaa alun perin aloille hakeutumiseen:

"[Alalle] olen vaihtanut, kun lapset kasvoi isoiksi ja mulla oli kolme lasta ja olin niiden kanssa kotona. Tein hommia kyllä, mutta etupässä iltahommia. Ja sitten mä päätin, että olin jo likempänä neljääkymmentä ja ei ollut oikein alaa missä olisin voinut hankkia sitä rahaa kunnolla. Ja sitten mä päätin, että mä vaihdan ne iltahommani päivätyöhön ja sitten läksin tähän nykyiseen työpaikkaani, jossa nyt olen ollut jo yli 20 vuotta." (nainen, haastattelu 3, kaupan ala)

Yksityisillä palvelualoilla yleiset osa-aikaiset työsuhteet ovat tarjonneet erityisesti pienten lasten äideille mahdollisuuden hoitaa lapsia kotona. Ongelmana on kuitenkin pidetty sitä, että osa-aikatyössä palkka jää 
TYÖN, PERHEEN JA

\section{AY-TOIMINNAN YHDIST $\ddot{M} I N E N$}

\section{ON KOLMINKERTAINEN}

\section{TAAKKA.}

kokoaikatyötä pienemmäksi, ja työvuoroja voi olla vaikea sovittaa yhteen perheen arjen kanssa (Salmi ym. 2016, 206). Erilaisten velvollisuuksien yhteensovittaminen muuttuu haastavaksi varsinkin silloin, kun perhevelvollisuuksiin ja epäsäännöllisiin työaikoihin on pystyttävä yhdistämään ay-toimintaa koskevat velvollisuudet.

Olen aiemmassa artikkelissani tuonut esille, miten luottamusmiestehtävään liittyy ajankäytöllisiä paineita esimerkiksi palvelutyön epäsäännöllisen ja tiiviin rytmin takia (Kainulainen 2020). Ajankäytön mahdollisuuksia voidaan pitää yhtenä keskeisenä luottamusmiesten ammattiyhdistysuria määrittävänä tekijänä (Kirton 2006). Työn, perheen ja ay-toiminnan yhdistäminen on kolminkertainen taakka (triple load), kuten näiden eri elämänalueiden yhdistämistä on aiemmissa tutkimuksissa kutsuttu. (Bradley ym. 2005, 226; Kirton 2006, 58.)

Luottamusmieheksi hakeutumistaan Aila selitti sillä, että häntä edeltävä luottamusmies ei ollut toiminut riittävän aktiivisesti työntekijöiden edustajana, joten hän päätti itse pyrkiä tehtävään ja asettautui ehdolle:

"[Yrityksessä] oli luottamusmiehenä mies, joka antoi mulle hyvin huonoja vastauksia ja kun kysyin miksi, niin hän vastasi, että siksi kun minä sanon. [--] Minä en tyytynyt siihen vastaukseen ja kun aikani häntä kuuntelin ja hänen toimikautensa oli päättymässä, niin ajattelin, että minäkin olen parempi. Minä pystyn jostakin selvittämään.”

Ajautuminen kuvaa aloille päätymisen ohella luottamusmiestehtävässä aloittamista. Tämä tuli esille urakerronnassa esimerkiksi niin, että tehtävään ei olisi aluksi haluttu tai siihen ryhtyminen vaati miettimistä (haastattelut 2, 10-12, 17, 23, 24). Luottamusmieheksi päätymisen syitä tarkastellut
Andreas Pekarek (2009) erottaa henkilökohtaisiksi syiksi oman kiinnostuksen, velvollisuudentunnon, altruistisen orientaation, itsevarmuuden, aiemman kokemuksen, ammattiliittoon sitoutumisen ja poliittisen ideologian. Ne ovat yhteneväisiä aineistossani esille tulevien syiden kanssa.

Yhdeksi keskeiseksi syyksi ilmeni kertomuksissa se, että muuten työpaikalla ei olisi luottamusmiestä välttämättä ollenkaan (haastattelut 7, 8, 10-12, 14, 18, 20). Tällöin luottamusmieheksi valikoiduttiin ikään kuin käytännön pakosta. Ailan tavoin luottamusmiehet olivat saattaneet lähteä haastamaan edeltäjäänsä. Edeltäjä oli voinut myös etsiä itselleen jatkajaa siirtyessään esimerkiksi eläkkeelle tai muihin tehtäviin. Tehtävään päätymisen syynä toimi myös se, että luottamusmiehet olivat aluksi lähteneet selvittämään omiin työehtoihinsa liittyviä ongelmia.

Vaikka luottamusmiesten uran alkuvaihetta koskeva urakerronta ei tue kuvaa määrätietoisesta ay-uran rakentamisesta, ja tehtävään pikemminkin kulkeuduttiin kuin hakeuduttiin, oma aktiivisuus vaikuttaa tehtävään päätymiseen. Siitä voi tulla ikään kuin "luonnollista" silloin, kun samankaltaista omaehtoista työehtoja koskevaa selvittelytyötä on tehty jo ennen luottamusmieheksi päätymistä.

"Mä kysyn uudestaan, että miksi sua kiinnostaa [luottamusmiehen tehtävä]?" (haastattelija)

”Ehkä se kun joskus on joutunut omia asioita selvittämään työnantajan kanssa ja jossain vaiheessa ajautui siihen, että selvitteli muidenkin asioita, kun kiinnosti saada asioita kuntoon, kun oli jotain epäkohtia. Sitten siinä vaan ajautui aina vaan syvemmälle ja sitten on tullut luottamustehtäviä sitä kautta niin kun kaikkea muutakin, että kaiketi se, että haluaa epäkohtiin puuttua ja saada korjattua." (nainen, haastattelu 16, ravintola-ala)

Keskeiseksi tekijäksi kertomuksissa nousee näkemys siitä, että työpaikalle tarvitaan luottamusmies ajamaan työntekijöiden etua. Niissä korostuu samoin työpaikkojen verrattain pieni koko. Työpaikan aytoiminnan kulttuuri eroaa tässä mielessä esimerkiksi suurista tehdasorganisaatioista, joissa ammattiosastotoiminnalla ja luottamusmiesorganisaatiolla voi olla 
pitkät perinteet ja vahva asema työntekijöiden edunvalvonnassa. Naisvaltaisilla yksityisillä palvelualoilla edunvalvonta työpaikalla on käytännössä etenkin pienissä toimipaikoissa luottamusmiesjärjestelmän perustusten rakentamista. Toiminta lepää yhden tai muutaman luottamusmiehen varassa. (Kainulainen 2020). Tästä huolimatta suurin osa luottamusmiehistä kertoi päätyneensä tehtävään siksi, että joku tai jotkut ovat työpaikalla sitä heille ehdottaneet, vaikka en kysynyt asiaa erikseen (haastateltavat 2, 4-15, 17-21, $23,24)$. Se on linjassa myös SAK:n luottamusmiesraportin kanssa siinä, että aloite luottamustehtävään ryhtymisestä tulee luottamusmiehille pääosin työtovereilta (Helin 2006, 77).

Ensimmäistä kauttaan toimivien toimipaikkakohtaisten luottamusmiesten ay-toiminta keskittyy yleensä oman työpaikan yksittäisten epäkohtien korjaamiseen, ja keskeiseksi sisällöksi muodostuu tiedon välittäminen työntekijöiden ja työnantajan välillä. Luottamusmiehet hoitavat tehtävää palkkatyönsä ohessa, eikä heillä yleensä vielä ole muita tehtäviä ay-liikkeessä. Luottamusmiestoimea lähestytään vastaantulevien yksittäisten tilanteiden näkökulmasta, eikä ay-aktiivisuus toimi elämänkulkua määrittävänä tekijänä. Arkinen yksittäisten asioiden kehittämistyö tulee esille esimerkiksi peruskurssilla toteuttamassani havainnoinnissa.

Kouluttaja pyytää luottamusmiehiä valitsemaan työpaikoiltaan tekemisen kohteen. Luottamusmiehet pohtivat hiljaa paikoillaan ja välillä opetustiloista kuuluu puheensorinaa. Kouluttaja kiertää keskustelemassa suunnitelmista ja sanoo, että hän kerää kaikkien tavoitteet taululle. Niissä nousee esille muun muassa: työntekijälistojen päivittäminen, jäsenhankinta, lakikirjan hankkiminen, työpaikan ilmoitustaulun päivittäminen, ruokailua koskeva ongelma, sekä palkkanauhojen nimekkeisiin ja vessojen siisteyteen liittyvät suunnitelmat.

Kurssin opetussisällöt käsittelevät tehtävän perustietoutta, kuten tiedonvälitystä, työehtoihin ja lainsäädäntöön tutustumista ja neuvottelutaitojen harjoittelemista. Kirjasin peruskurssilla muistiin osallistujien siihen liittämiä odotuksia. Ne koskivat esimerkiksi neuvottelutaitoja, esimerkkejä käytännön vaikuttamisesta, itsevarmuutta, ongelmanratkaisutaitoja, erilaisia näkökulmia, keskustelua ja verkostoitumista. Myös aiemmassa tutkimuksessa on osoitettu (Kirton 2006, 52-53), miten alkuvaiheessa ayuraa olevien naisten pyrkimyksenä on ensisijaisesti kehittyä tehtävässä kokemusten ja ammattiliiton tarjoaman koulutuksen kautta, ei niinkään edetä ay-uralla.

\section{Kehityskertomus - ammattiyhdistysaktiiviksi}

Aila koki kasvaneensa ay-aktiiviksi askel askeleelta. Hän oli aloittanut luottamusmiehenä ilman aiempaa kokemusta ja piti tehtävän hoitamiselle tärkeänä ammattiliiton antamaa apua, vertaistukea muilta luottamusmiehiltä ja ammattiliiton tarjoamia luottamusmieskoulutuksia. Aila piti oikeudenmukaisuuden ja tasa-arvon ihanteita sekä työntekijöiden edustamista luottamusmiesten ay-toiminnan eteenpäin vievänä voimana. Hän kuvasi ay-aktiiviksi kehittymistään seuraavasti:

"Sitä mennään portaittain sitten eteenpäin, rohkeus kasvaa ja osaaminen ja kaikki. [--] Jotenkin se on vaan semmoinen polku, jota lähdetään kulkemaan. [--] Oikeastaan sitä ei voi ihan suoraan verrata mihinkään ammatinvalintakysymykseen ihan suoraan, mutta miksei se vähän samansuuntaista ole. Kyllähän siellä tulee niitä portaita, että tähän minulla riittää valmiudet, entäs tuohon ja entäs tuohon. Nälkä kasvaa syödessä."

Varsinkin pitkään luottamusmiestehtävässä toimineilla päätoimisilla luottamusmiehillä ammattiyhdistystoiminta on olennainen osa arkea, sillä tehtävään sisältyvät vastuut ja muu ajanviete vievät aikaa. Päätoimisen pääluottamusmiehen toimi voi toisaalta tuoda työntekijöille toivottua säännönmukaisuutta, etenkin jos se niin sanotusti vapauttaa heidät yksityisillä palvelualoilla yleisestä vuorotyöskentelystä, vaikka tehtävää hoidetaan välillä sovittujen työaikojen ulkopuolella. Päätoimisen luottamusmiehen tehtävä muistuttaa tältä osin enemmän toimihenkilötyötä, joissa on suurempi autonomia ja paremmat mahdollisuudet vaikuttaa työn organisoimiseen 
NAisista AY-AKTIIVEINA

\section{EIVÄT PIT ̈̈NEET ITSEÄ̈̈N}

\section{TOIMIPAIKKAKOHTAISET}

\section{JA PIENTEN YRITYSTEN}

\section{LUOTTAMUSMIEHET.}

kuin suorittavissa töissä (esim. Julkunen 2008). Tehtävä sisältää kokouksia ja edellyttää kognitiivisia valmiuksia, kuten tiedonkäsittelyä, henkilökohtaista ongelmanratkaisukykyä ja vuorovaikutustaitoja.

”Ei niissä [työtehtävissä] ole mitään yhtäläisyyttä. Että kun kokin työhän on fyysisesti hirveen raskasta ja se on suorittavaa työtä ja hyvin semmoista, pakkotahtista työtä ja aikatauluista pitää pitää kiinni ihan mielettömästi. Ja sitten taas pääluottamusmiehen työssä, niin enimpi aika menee siinä, että sä istut kabineteissa ja kokouksissa ja, sellaista aivotyöskentelyä hyvin paljon ja yksin puurtamista, että kun sä mietit ihmisten ongelmia ja miten sä lähdet niitä viemään eteenpäin. Että niissä ei ole mun mielestäni mitään yhtymäkohtaa [nauraa]." (nainen, haastattelu 17, ravintola-ala)

Ay-aktiiviksi määrittäminen tapahtuu aineistossa yleensä sen perusteella, miten näkyvässä ja merkittävässä asemassa haastateltavat kokevat ay-liikkeeseen kytkeytyvät toimet elämässään sekä miten monipuolisesti he toimivat erilaisissa ammattiliiton asemissa, kuten hallituksessa, valtuustossa, valiokunnissa ja sopimusalatoimikunnissa. Tämän takia harva toimipaikkakohtaisista ja varsinkaan ensimmäisen kauden luottamusmiehistä mielsi itseään ay-aktiiviksi. Sen sijaan toiminnassa pidempään mukana olleet, päätoimisena tehtävää suorittaneet pitivät kaikki itseään ay-aktiiveina. Heidän määritelmissään aktiiviksi tulkitsemisen kynnys oli myös vähemmän aikaa tehtävässä toimineita luottamusmiehiä matalampi. Haastatelluista 15 naisesta kuusi ei pitänyt itseään aktiivina, mutta yhdeksästä haastatellusta miehestä vain kaksi ei pitänyt itseään ay-aktiivina. Naisista ay-aktiivina eivät pitäneet toimipaikkakohtaiset ja pienten yritysten luottamusmiehet. Miehillä jako ei ollut yhtä selvä, ja myös osa toimipaikkakohtaisista ja pienten yritysten luottamusmiehistä laski itsensä aktiiviksi (haastateltavat: 8, 20, 23).

Luottamusmiesten urakerronnassa tulee esille, miten erityisesti sellaiset haastateltavat, jotka eivät nähneet itseään ay-aktiiveina, rajasivat aktiiveiksi vain kaikkein näkyvimmät toimijat. Kuva "poikkeuksellisen aktiivisista" työntekijöiden edustajista toistui luottamusmiesten aktiiveille antamissa määritelmissä. Itsensä aktiiviksi mieltäminen riippui erityisesti siitä, positioivatko luottamusmiehet itsensä suhteessa rivijäseniin vai aktiivisimpiin aktiiveihin.

”No jos mä vertaan johonkin oikein, mitä mä kuvittelen ay-aktiivilla niin en ole, sellainen ayaktiivi, että mä, että sen PAMin voisi melkein lukea tästä otsasta niin en, en ole. Et en mä tiedä, en tuputa sitä niin kuin uskontoa kellekään.” (nainen, haastattelu 11, kaupan ala)

”Niin että mä sitten ajattelen, että se [aktiivi] on ehkä enemmän esillä ja enemmän just toiminnassa mukana ja tuo itseensä paremmin esille. [--] Jotenkin ay-aktiivisen mielikuva tulee heti, että se on niin kuin liput heilumassa jossain eduskuntatalon portailla [naurahtaa], mutta siis että totta kai se on siis kaikkea muuta. Mutta se että, en ehkä ole ajatellut itseäni ay-aktiivisena." (nainen, haastattelu 10, ravintola-ala)

”Niin niin, se on sitten tietysti katsojan silmässä, että olenko mä ay-aktiivi. En mä ole semmoinen, että mä jakelen jotain flaijereita, että PAM sitä PAM tätä, vaan että mä kerron uusille työntekijöille, että kuulutaan esim. ammattiliittoon ja olisi oikein suotavaa, että jos ja kun apua tarvitsette ja kysyttävää tulee, niin se käytännössä edellyttää sen, että kuuluu ammattiliittoon." (mies, haastattelu 19 , vartiointiala)

Väljimmissä luottamusmiesten antamissa ay-aktiivien määritelmissä aktiiveiksi määritettiin kaikki muut paitsi liiton passiivisimmat rivijäsenet. Toisin sanoen kiinnostus työtehtäviä koskeviin asioihin riitti siihen, että tulkittiin aktiiviksi. 


\section{P ̈̈̈̈LUOTTAMUSMIESTEN}

\section{TEHT $\ddot{A} V \ddot{A A}$ PIDET $\ddot{A} \ddot{A}$}

\section{HENKISESTI KUORMITTAVANA.}

Monet ay-aktiivin toimet, kuten ammattiosastojen kokoukset ja ammattiliiton järjestämät tapahtumat, sijoittuvat normaalien työaikojen ulkopuolelle, minkä vuoksi aktiivina toimiminen vaatii oman vapaa-ajan käyttämistä. Pääluottamusmiesten tehtävää on pidetty henkisesti kuormittavana, joka vaatii tekijältään vapaa-ajan uhraamista ja omistautunutta asennetta (esim. Kirton 2006; Heiskanen \& Lavikka 2014; Kainulainen 2018; Kainulainen 2020). Samalla kun ajankäyttö on keskeinen ay-aktiivisuutta määrittävä tekijä, se on olennainen toimintaa sukupuolittava tekijä (esim. Lawrence 1994; Kirton 2006; Kainulainen 2020). Aineistossa tulee esille työn intensiivisyyden ohella sen ulkopuolisen elämän kuormittavuus. Aikaa vievän ammattiyhdistystoiminnan yhteensovittaminen oman vapaa-ajan kanssa koskee erityisesti perheellisiä luottamusmiehiä.

"Ehkä se tarjonta [harrastuksissa] on niin toisenlaista nyt. [--] On lapsillekin harrastusmahdollisuuksia niin paljon, että loppuu oikeasti vuorokaudesta tunnit. Ja sitten taas toisaalta keskeinen ongelma on se, että työajat ovat useilla aloilla jo niin toista, kun kahdeksasta neljään arkisin. [--] kaikkina vuorokauden aikoina sulla voi olla työvuoro, niin sitten kun sulla on se vapaa hetki, vaikka silloin olisikin tarjolla jotain niin sä et vaa jaksa lähteä. Että saisi sitä omaakin aikaa. Mutta että onko se runsaudenpula sitten mikä osaltaan vie." (nainen, haastattelu 15, kaupan ala)

Korvajärvi (2002; 2004) on tuonut esille sen, miten työorganisaatioissa vallitsee oletus sukupuolineutraalisuudesta ja sukupuolten välisestä harmoniasta sekä siitä, miten sukupuolella ei usein koeta olevan merkitystä. Sukupuolen poispyyhkiytymisen on osoitettu tuottavan yksityisille palvelualoille sukupuolittuneen edunvalvonnan kentän (Kainulainen \& Saari 2014).
Sukupuolen merkityksen vähätteleminen kuvastaa samalla luottamusmiesten urakerrontaa. Haastateltava saattoi aluksi todeta, miten luottamusmiehenä toimimisessa sukupuolella ei ollut väliä, ja kyse oli yksilöistä. Toisessa kohtaa hän saattoi todeta, että naisena häneen oli suhtauduttu ay-toiminnassa eri tavalla kuin mieheen suhtauduttaisiin (ks. myös Kainulainen \& Saari 2014).

Ajankäyttöä pohtineen kaupanalan luottamusmiehen haastattelussa tämä ristiriita nousi hyvin konkreettisesti esille. Hän koki, että sukupuolella ei ollut merkitystä, ja kyse oli yksilön omasta aktiivisuudesta, mutta pohti samalla, miten ammattiosaston kokouksissa oli imetetty aivan pieniä vauvoja.

"Tietysti silloin, jos on ihan pieniä vauvoja, niin vauvat on vähän enemmän kiinni siinä äidissä kun se äiti on se joka pystyy imettämisen hoitamaan. Mutta sitten taas mitä muistaa ammattiosastonkin johtokunnan kokouksista, niin ne aktiivit, jotka aktiiveja oli, niin on siellä alle viikon ikäisiä vauvoja imetetty siinä kokouksen lomassa. Että se kai sitten taas riippuu siitä omasta aktiivisuudesta, omasta kiinnostuksesta että haluaako olla sitten yhtään pois. Mutta en mä usko et sukupuolella on sillä lailla merkitystä." (nainen, haastattelu 15, kaupan ala)

Vauvoja ei kuitenkaan ole mahdollista imettää kaikissa kokouksissa, minkä vuoksi hoivavastuun kasautuminen äideille toimii luottamusmiesten uramahdollisuuksia rajaavana sukupuolistavana käytäntönä.

Sukupuoli jäsentää kokemuksia myös siitä, millä tavoin luottamusmies otetaan tehtävässään vastaan (Bradley 1999; Kainulainen \& Saari 2014). Ravintola-alalla päätoimisena luottamusmiehenä toimiva nainen tuo selvästi esille uramahdollisuuksien sukupuolittuneen luonteen yhdistämällä ay-toiminnan perinteen ja etenemismahdollisuuksien avautumisen miehiin (ks. myös Bradley 1999; Kirton 2006). Naisten uraetenemistä haittaaville rakenteellisille ongelmille haastateltava näkee kuitenkin ratkaisuksi naisten yksilöllisen päätöksenteon - tarkemmin sanottuna heidän oman rohkeutensa. Näin ay-toiminnan sukupuolittuneita rakenteita tulisi hänen näkemyksensä mukaan haastaa yksilöllisillä valinnoilla. 


\section{SUURTEN YRITYSTEN}

\section{P $\ddot{A}$ TOIMISIIN LUOTTAMUSMIES-}

\section{TEHT ̈̈VIIN VOI LIITTY ̈̈}

KOVAA KILPAILUA.

\begin{abstract}
"Mun mielestäni naisia pitäisi olla vielä enemmän, ja sitten naisten pitäisi olla vielä rohkeampia. Että tietysti tässä on pitkät perinteet, että miehet on ollut ne, jotka on aikanaan ollut niitä enemmän vaikuttajia." (Nainen, haastattelu 17, ravintola-ala)

"Puhutko sä luottamusmiehistä vai, PAMin jäsenistä vai sitten tästä hallinnon, siis näistä eri, PAMin hallituksista ja SAK:n toiminnasta?" (haastattelija)

”No kaikista näistä luottamustehtävistä, koska siellä pitäisi olla vaan vielä enemmän naisia. Ja naisten rohkeammin tulla mukaan. Ja nimenomaan nuorten naisten vielä lisäksi, että olisi sitten sitä jatkumoa. Että miesten on jotenkin paljon helpompi mennä ja miehet saa helpommin paikkoja." (nainen, haastattelu 17, ravintola-ala)
\end{abstract}

Haastateltavan vastauksessa sukupuoli on ammattiliiton organisatorisia urakehityksen mahdollisuuksia jäsentävä tekijä, mutta samalla se tulkitaan yksilön henkilökohtaiseksi ratkaisuksi. Sukupuoli vaikuttaa mahdollisuuksiin kohota ay-liikkeen uraportailla, ja ay-aktiiveihin liitettyjä sukupuolittuneita oletuksia tuotetaan työpaikkojen käytännöissä. Rakenteellisten erojen tunnistaminen ja samanaikainen sukupuolen vaikutuksen kieltäminen ay-toiminnassa on yksi tapa tuottaa käsitystä sen sukupuolineutraalista luonteesta ja vahvistaa sen sukupuolistavia käytäntöjä (Kainulainen \& Saari 2014).

Nuorilla naisilla sukupuolen ohella ikä vaikeuttaa ay-aktiivin uralla etenemistä, sillä aktiiveina he tulevat haastaneiksi sekä ikää että sukupuolta koskevia aytoiminnan perinteitä. Sukupuolittuneet ay-toiminnan rakenteet selittävät osaltaan sitä, miksi miehillä on jäsenten sukupuolijakaumaan suhteutettuna edelleen yliedustus ammattiliiton luottamustehtävissä.

\section{Lopetuskertomus - luottamusmiestehtävän jälkeen}

Aila on toiminut luottamusmiehen tehtävissä toistakymmentä vuotta. Hän on ollut aktiivinen ammattiosastonsa toiminnassa, ja lopulta hänet on valittu ammattiliiton valtuustoon ja hallitukseen. Aila on tyytyväinen saavutuksiinsa työurallaan. Nykyisestä asemastaan ay-liikkeessä Aila toteaa nauraen: "Mä en varmaan ihan oikeasti kykene enää tämän enempään ja sitten toisekseen ei ole kuin liittopuheenjohtajan paikka ja toimitusjohtajan paikka siellä yrityksessä, että mä olen saavuttanut jo ihan oikeastaan riittävästi."

Luottamusmiehillä on tehtävässään muita työntekijöitä vahvempi irtisanomissuoja, mutta siitä huolimatta heidän urakerronnassaan on havaittavissa myös tehtävän jatkoon liittyvää epävarmuutta. Suurten yritysten päätoimisiin luottamusmiestehtäviin ja erilaisiin ammattiliiton hallinnollisiin asemiin voi liittyä kovaakin kilpailua, mikä synnyttää huolta myös mahdollisesta luottamusmiesvaalien häviämisestä. Luottamusmiesten aktiivisinta kärkeä edustavien päätoimisten pääluottamusmiesten osuus on myös hyvin pieni, sillä heitä on luottamusmiehistä vain neljä prosenttia. Kilpailu tehtävistä tai luottamusmiestehtävän mahdollista jatkumista koskeva pohdinta tulivat esille usean päätoimisen luottamusmiehen haastattelussa (haastateltavat: 1, 2, 4, 6, 9, 16, 17).

Päätoimisilla luottamusmiehillä huolta voi aiheuttaa sekin, että luottamusmieskausi kestää vain kaksi vuotta. Epävarmuuden ohella tähän saattaa liittyä katkeruuden ja epäreiluuden tunteita. Olennaista näiden kielteisten tunteiden kannalta on luottamusmiesten subjektiivisen ja objektiivisen uran välille muodostuva ristiriita. Toisin sanoen luottamusmiestoiminnalle uhrataan aikaa ja omia voimavaroja, mutta panokset eivät kuitenkaan aina näy tehtävän jatkumisena tai urakehityksenä.

Luottamusmiestehtävistä voi olla vaikeaa palata entisiin työtehtäviin, koska niitä koskevaa ammattitaitoa ei ole ollut mahdollista pitää yllä, ja fyysisesti kuormittamiin palvelualojen töihin palaaminen saattaa olla varsinkin vanhemmille päätoimisille luottamusmiehille vaikeaa. Lisäksi ay-aktiivina hankittua osaamista voi olla hankalaa hyödyntää muihin työtehtäviin hakemisessa. 
TYÖNANTAJALLE

\section{LUOTTAMUSMIES EDUSTAA}

AMMATTILIITTOA JA

AMMATTILIITOLLE OMAA

YRITYST $\ddot{A} \ddot{N}$.

"No siinä varmasti katkeruutta, jos sut syrjäytetään siit pois. Ajattele mua esimerkiksi. Mä olen nyt ollut yli 20 vuotta, ja mut syrjäytettäisiin nyt näissä syksyn vaaleissa. Mitä mä tekisin sitten? Miettisin kyllä hetken aikaa et hetkinen että, yli 20 vuotta elämästä mä annoin ay-liikkeelle, ja nyt mun pitää keksii et mitä mä teen mun elämässä, kun mun oma ammattitaito on mennyt. Mä en voi palata sinne mun omaan ammattiin, kun mä en ole sitä 20 vuoteen tehnyt. Niin nyt mun pitäisi kouluttautua omatoimisesti johonkin uuteen." (nainen, haastattelu 17, ravintola-ala)

Luottamusmiesten halu jatkaa tehtävässään voi aiheuttaa työntekijöille ja ammattiliitolle ongelmia, sillä jatkon varmistamista koskevaa vaalityötä saatetaan joutua tekemään luottamustehtävän hoitamisen kustannuksella. Toisin sanoen oman urakehityksen turvaaminen voi asettua ristiriitaan luottamukseen perustuvan demokraattisesti luottamusmiesvaaleissa valitun yhteisön edustajan aseman kanssa. Päätoimisilla luottamusmiehillä uramahdollisuuksien selkeyttäminen voi vähentää stressiä ja kokemusta yksin jäämisestä. Kun kysyin ravintola-alan luottamusmieheltä (nainen, haastattelu 17), saattaisiko luottamusmiehen tehtävää pitää vaihtoehtona yrityksen urapoluille, hän vastasi näin:

”No toi on kuule äärettömän hyvä kysymys ja toi olisi mun mielestäni semmoinen mikä kannattaisi ottaa sellaiseen oikein yleiseenkin pohdintaan. Sen takia että, sitä ei ole varmaan koskaan nähty semmoisena vaihtoehtona. Ja sitä ei ole koskaan kehitetty semmoisena vaihtoehtona oikeasti. Että koska siinä on niin kova se kamppailu aina et kuka sinne pääsee ja, sitten siitä, että kuka siitä pitää huolta sitten siitä urakehityksestä. Oikeasti kun ajatellaan että työnantajallehan sä olet vähän semmoinen pikku paha, ja sitten oikeasti niin ethän sä ole liitonkaan, työntekijä. Niin ei se liittokaan susta huolehdi. Niin sun pitää itse itsestäsi huolehtia. Niin sikäli, se, onki hyvä kysymys, että onko se uravaihtoehto." (nainen, haastattelu 17, ravintola-ala)

Haastateltavan kertomuksessa tulee esille luottamusmiehen aseman kahtiajakoisuus ja sitä koskeva jännite. Työnantajalle luottamusmies edustaa tehtävänsä takia ammattiliittoa ja ammattiliitolle omaa yritystään.

Kielteisistä piirteistä huolimatta luottamusmiestoiminta koetaan aineistossa myös palkitsevana. Esimerkiksi Aila totesi, että "toisaalta sitten siitä [luottamusmiestoiminnan] palkitsevuudesta tulee ehkä harvemmin puhuttua, että näihin liittyy näihin asemiin sitten niin paljon sellaista arvostusta ja mahdollisuutta vaikuttaa asioihin".

Toinen kaupan alan päätoiminen luottamusmies totesi pohtiessaan tulevien vaalien mahdollista häviämistä, että tehtävän tärkeydestä huolimatta se ei kuitenkaan ole hänelle "sellainen elämän ja kuoleman paikka" (haastattelu 2, nainen). Ammattiyhdistysura ei myöskään välttämättä pääty luottamusmiesvaalien häviämiseen tai entisiin työtehtäviin palaamiseen. Yhtenä mahdollisena luottamusmiesten urakehityksen päätepisteenä on pidetty ammattiliiton toimitsijaksi, palkatuksi toimihenkilöksi, kohoamista. Tämä tulee esille esimerkiksi luottamusmiesten jatkokurssilla tuotetun havainnointiaineiston episodissa, jossa vierailemme PAMin aluetoimistossa:

"Aluetoimitsija kertoo nykyisestä työstään ja kokemuksistaan pääluottamusmiehen tehtävissä. [--] Hän toteaa pohdiskelevaan sävyyn, että onko toimitsijaksi päätyminen 'se palkinto tehdystä luottamusmiestyöstä'. Toimitsija kertoo tehtävänsä korkeasta työmäärästä ja sen muista ikävistä puolista, sekä jatkaa puhumalla siitä, miten luottamusmiesvuosinaan hän kyllästyi 'tappelemaan aina samoista asioista', eli kaupan alan työntekijöiden lisätunneista. [--] Toimitsija vertaa nykyistä työtään luottamusmiestehtävään niin, että nykyisessä työssä asiat ovat paremmin siinä mielessä, että jutut alkavat, mutta ne myös päättyvät." 
AY-TOIMINTA TARJOAA

MATALASTI KOULUTETUILLE

TYO̊NTEKIJÖILLE URAKEHITYKSEN

MAHDOLLISUUKSIA.

Selkein ero toimitsijoiden työn ja luottamusmiestehtävän välillä on se, että toimitsijat eivät ole enää samalla tavalla riippuvaisia kentän hyväksynnästä. Erään PAMin toimitsijan kanssa käymäni keskustelun perusteella luottamusmiestausta mahdollistaa edelleen ammattiliittoon työllistymisen esimerkiksi sopimusasioiden ja järjestötehtävien pariin sekä aluetoimistoihin, mutta samalla ammattiliitto on yhä enemmän asiantuntijaorganisaatio, jonka moniin tehtäviin edellytetään korkeaa koulutustasoa (henkilökohtainen tiedonanto PAM 10.6.2019). Tärkeää on kuitenkin huomata, että ammattiliiton toimitsijoiksi luottamusmiehistä päätyy lopulta vain murto-osa.

\section{POHDINTA}

Tarkastelin artikkelissa PAMin luottamusmiesten tehtävään liittyvää urakerrontaa osana luottamusmiesten elämänkulkua. Tulokset tuovat esille sen, miten työntekijöiden edustajana toimiminen tarjoaa luottamusmiehille mahdollisuuksia vaikuttaa työntekijöiden työehtoihin, merkityksellistää omaa työtään ja kehittää osaamistaan. Ay-toimintaan osallistuminen tarjoaa matalasti koulutetuille työntekijöille urakehityksen mahdollisuuksia aloilla, joihin ei yleensä liitetä urakehityksen piirteitä. Varsinkin päätoimisesti tehtävää hoitavilla luottamusmiehillä ay-toiminta muodostui tärkeäksi osaksi elämää myös työpaikan ulkopuolella. Tässä mielessä se muistuttaa perinteistä arkikäsitystä urasta.

Ammattiyhdistystoiminnalle annetaan ja se myös ottaa työn ulkopuolista aikaa. Luottamusmiesten uralle antamat merkitykset kietoutuvat muun muassa työntekijöiden kollektiivisten etujen valvonnan, oman asiantuntijuuden rakentumisen ja risteävien urapolkujen tasapainottamisen ympärille. Tulokset tukevat aiempia ammattiyhdistysaktiiveja käsitteleviä tutkimuksia siinä, että ay-toimintaan osallistuminen tuo työntekijöille kaivattua vaihtelua ja tarjoaa sisältöä muuhun elämään (Kirton 2006).

Pätkätyöntekijöiden urakerrontaa tutkinut Sikke Leinikki $(2009,45)$ on todennut, että urakerronnalla luodaan uralle jatkuvuuden tunnetta ja uskottavuutta. Erityisesti päätoimisten luottamusmiesten urakerronnassa on havaittavissa nousujohteinen juoni, jossa eteneminen on tapahtunut askeleittain erilaisten tehtävien ja toimien lisääntymisenä. Ay-toiminnan kautta avautuu mahdollisuus siirtyä suorittavasta palvelutyöstä tehtäviin, jotka muistuttavat sekä tiedollisten vaatimusten että työntekijöiden autonomian suhteen luonteeltaan enemmän toimihenkilötyötä (ks. Julkunen 2008). Tehtävässä edellytetään taitoja, joita ei ole totuttu liittämään matalien koulutusvaatimusten matalapalkka-aloihin vaan koulutusta vaativiin asiantuntijatehtäviin.

Suurten työntekijämäärien edustaminen edellyttää johtamistaitojen ohella tiedollisia valmiuksia käsitellä ja tuottaa monenlaista informaatiota. Lisäksi se edellyttää vastuuta, paineensietokykyä ja tilivelvollisuutta jäsenille (esim. Heiskanen \& Lavikka 2014; Kainulainen 2018; Kainulainen 2020,). Toisaalta tehtävä voi tarjota päätoimisille luottamusmiehille myös työhuoneen, matkustamista ja suhteellisen vapaasti päätettävät työajat.

Tutkimuksen tulokset tuovat esille, miten naisten ay-uria koskevat hyvin samanlaiset uraesteet kuin monia muita työuria. Velvollisuuksien yhdistämistä koskevien vaikeuksien voidaan olettaa korostuvan erityisesti naisvaltaisilla palvelualoilla, kuten kaupassa ja majoitus- ja ravitsemustoiminnassa, sillä työtä tehdään niillä usein niin sanottujen normaalityöaikojen ulkopuolella iltaisin ja viikonloppuisin, minkä vuoksi työvuorojen ennustaminen on erityisen hankalaa (Kainulainen 2020). Ay-uran rakentumisen kannalta erityisesti perheen ja työn yhteensovittaminen, miehiä suosiva sosiaalinen ympäristö ja edunvalvonnan miehiset perinteet asettavat naisten uraetenemiselle haasteita (ks. myös. Lawrence 1994; Bradley1999; Kirton 2006; Kainulainen \& Saari 2014). Sukupuoli jäsentää luottamusmiesten uramahdollisuuksia, vaikka ammattiyhdistystoiminnan tarjoamiin tehtäviin hakeutumista lähestytään sukupuolineutraalisti "omana valintana”. 
KeINOT UUSIEN AKTIIVIEN

\author{
HANKKIMISEEN VAIKUTTAVAT \\ RAJALLISILTA, VAIKKA SIIHEN \\ ON PAINEITA.
}

Vaikka aineistossa toistuvat kuvaukset aloille ja luottamusmiestehtävään ajautumisesta, luottamusmiehen ura voi olla määrätietoisen pyrkimisen tulos etenkin päätoimisilla luottamusmiehillä. Heillä luottamusmiestehtävässä on havaittavissa ammatillisen kasvun piirteitä (ks. Wallin 2007). Ensinnäkin tehtävä edellyttää aktiivista oman osaamisen kehittämistä esimerkiksi luottamusmieskoulutuksiin osallistumalla, jotta jäsenten kysymyksiin on mahdollista vastata. Toiseksi tehtävään sisältyy korkea sitoutumisen vaatimus esimerkiksi sen edellyttämän paineensietokyvyn ja suuren työmäärän vuoksi (esim. Heiskanen \& Lavikka 2014, 165). Ay-aktiivin ura voi tuoda työn epäsäännöllisyyteen tottuneille palvelutyöntekijöille kaivattua ennustettavuutta, mutta samalla erityisesti päätoimisten luottamusmiesten paikoista käyty kilpailu lisää uran tulevaisuudesta koettua epävarmuutta.

Tutkimuksissa työntekijöiden ajankäytöstä on tuotu esille, miten kiireen kokemukset ovat lisääntyneet työelämässä, ja samalla on alettu puhua 24 tunnin yhteiskunnasta (esim. Epstein ja Kalleberg 2001). Työelämän muuttuessa yhä hektisemmäksi ja haukatessa ihmisten vapaa-ajasta yhä suuremman osan, ammattiliittojen on tärkeää pohtia, miten työntekijöillä riittää aikaa ja jaksamista ammattiyhdistysaktiivisuudelle (ks. myös Kainulainen 2020). Näiden muutosten takia ei voida pitää yllättävänä, että luottamusmiesten määrä vähenee (vrt. luottamusmiesten määrä Kainulainen 2018), etenkin kun huomioidaan yleisesti ay-liikkeen aseman heikentyminen yhteiskunnassa (ks. esim. Julkunen 2008).

Uusien aktiivien löytäminen olisi ammattiliittojen tulevaisuuden kannalta erityisen tärkeää siksikin, että niiden aktiivijäsenistö ikääntyy. Lisäksi paikallinen sopiminen lisää luottamusmiesten merkitystä tulevaisuudessa. Keinot uusien aktiivien hankkimiseen vaikuttavat kuitenkin rajallisilta. Edellytyksenä on, että ammattiliitot huomioivat työntekijöiden erilaiset mahdollisuudet osallistua ay-toimintaan. Lisäksi niiden tulee pohtia, mitä ne voivat tarjota toiminnassa mukana oleville ja siihen aikaa uhraaville työpaikkojen aktiiveille.

Yhtenä kehittämisen kohteena päätoimisten luottamusmiesten haastatteluissa tuli esille tulevaisuuden uramahdollisuuksien selvittämisen ja kehittämisen ammattiliiton puolelta. Kysymykseksi nousee tällöin se, mitä sen jälkeen, kun on antanut ay-liikkeelle vuosia aikaansa ja osaamistaan, mutta ura voi päättyä seuraaviin vaaleihin, tai sitä seuraaviin. Päätoimisilla pääluottamusmiehillä vaihtoehtona on tehtävän päättyessä palata takaisin niihin työtehtäviin, joista he ovat tehtävään lähteneet. Käytännössä se ei kuitenkaan vaikuta kovinkaan todennäköiseltä tulevaisuudelta niille, jotka ovat olleet näistä töistä pitkään poissa.

Luottamusmiesten mahdollisuudet siirtyä toiselle työuralle vaikuttavat parantuneen 2010-luvun loppupuolella, sillä esimerkiksi Palkansaajien koulutussäätiön omistama Kiljavan opisto on alkanut tarjota yhdessä Humanistisen ammattikorkeakoulun (HUMAK) kanssa toteutettavia avoimen korkeakoulun väyläopintoja, joiden kautta on mahdollista päästä riittävien opintomäärien täyttyessä opiskelemaan varsinaiselle ammattikorkeakoulun linjalle. Tämä polku edellyttää kuitenkin opiskeluvalmiuksia, joita kaikilla matalasti kouluttautuneilla luottamusmiehillä ei välttämättä ole. Nähtäväksi jää, millaisen roolin ammattiliitot ottavat siinä, miten niiden aktiiveja tai entisiä aktiiveja valmennettaisiin kohti uutta uraa.

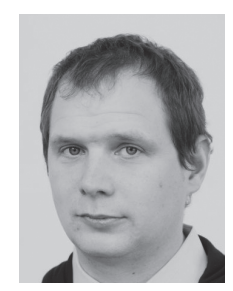

VILLE KAINULAINEN

$\mathrm{KM}$, tohtorikoulutettava

Gepoco-projekti

Tampereen yliopisto

(iD) https://orcid.org/0000-00024343-543X

${ }^{1}$ Koko aineistokokonaisuudesta rajasin tästä artikkelista pois kolmen parihaastattelun ohella, luottamusmiesten työpaikoilla (4 päivää), luottamusmiestapaamisessa (2 päivää) tuotetun havainnointiaineiston ja kaksi ryhmäkeskustelua. 
Acker, J. (1997). Foreword by Joan Acker. Teoksessa L. Rantalaiho \& T. Heiskanen (toim.): Gendered Practices in Working Life. New York: St. Martin's Press., ix-xi. DOI 10.1007/978-1-349-25285-5.

Acker J. (1990a). Hierarchies, jobs, bodies: A theory of gendered organizations. Gender and Society (4)2, 139-158. DOI:10.1177/089124390004002002.

Acker J. (1990b). Samanarvoinen työ. Tutkimus työelämän sukupuolistuneista rakenteista. Tampere: Vastapaino.

Ahtiainen, L. (2019). Palkansaajien järjestäytyminen vuonna 2017. Työ- ja elinkeinoministeriö. Työ- ja elinkeinoministeriön julkaisuja 2019:10.

Ahtiainen, L. (2015). Järjestötutkimus 2015. Palvelualojen ammattiliitto PAM, julkaisuja 2/2015.

Angrosino, M. (2007). Doing Ethnographic and Observational Research. London: SAGE. DOI: 10.4135/9781849208932.

Arthur, M. \& Rousseau, D. (1996). The Boundaryless Career: A New Employment Principle for a New Organizational Era.

Bradley, H. (1999). Gender and Power in the Workplace: Analysing the Impact of Economic Change, Basingstoke: Macmillan Press. DOI: 10.1007/978-1349-27050-7.

Bradley, H., Healy, G. \& Mukherjee, N. (2005). Multiple burdens: problems of work-life balance for ethnic minority trade union activist women. Teoksessa D. M. Houston (toim.): Work-Life Balance in the 21st Century. Basingstoke: Palgrave Macmillan, 211-229. DOI: 10.1057/9780230373594_1.

Collin, A. \& Watts, A. G. (1996): The death and transfiguration of career-and of career guidance? British Journal of Guidance \& Counselling (24)3, 385398. DOI: 10.1080/03069889608253023.

Cortazzi, M. (2001). Narrative analysis in ethnography. Teoksessa P. Atkinson, A. Coffey, S. Delamont, J. Lofland, \& L. Lofland (toim.) Handbook of ethnography. Thousand Oaks: Sage, 384-394. DOI: 10.4135/9781848608337.n26.

Dølvik, J. E. \& Waddington, J. (2002). Private Sector Services: Challenges to European Trade Unions. Transfer: European Review of Labour and Research (8)3, 356-376. DOI: 10.1177/102425890200800304.

Epstein, C. F. \& Kalleberg, A. L. (2001). Time and the Sociology of Work: Issues and Implications. Work and Occupations (28)1, 5-16. DOI: 10.1177/0730888401028001002.

Heikkinen, H. (2010). Narratiivinen tutkimus - todellisuus kertomuksena. Teoksessa J. Aaltola \& R. Valli (toim.) Ikkunoita tutkimusmetodeihin 2. Näkökulmia aloittelevalle tutkijalle tutkimuksen teoreettisiin lähtökohtiin ja analyysimenetelmiin. 3. painos. Jyväskylä: PS-kustannus, 143-159.
Heiskanen, T. \& Lavikka, R. (2014). Pääluottamusmies Aliisan tarina. Aikuiskasvatus (34)3, 164-177.

Helin, J. (2006). Ansaittua luottamusta. SAK:n järjestötutkimus 2005. Luottamushenkilöraportti. Oulu: SAK.

Hennequin, E. (2007). What "career success" means to blue-collar workers. Career Development International (12)6, 565-581. DOI: 10.1108/13620430710822029

Huttunen, L. \& Homanen, R. (2017). Etnografinen haastattelu. Teoksessa M. Hyvärinen, P. Nikander \& J. Ruusuvuori (toim.) Tutkimushaastattelun käsikirja. Tampere: Vastapaino, 131-152.

Hyvärinen, M. (2017) Haastattelun maailma. Teoksessa M. Hyvärinen, P. Nikander \& J. Ruusuvuori (toim.) Tutkimushaastattelun käsikirja. Tampere: Vastapaino, 11-45.

Hämeenaho, P. \& Koskinen-Koivisto, E. (2014). Etnografian ulottuvuudet ja mahdollisuudet. Teoksessa P. Hämeenaho, \& E. Koskinen-Koivisto (toim.), Moniulotteinen etnografia, 7-31.

Julkunen, R. (2008). Uuden työn paradoksit. Keskusteluja 2000-luvun työprosess(e)ista. Tampere: Vastapaino.

Kauhanen, M. (2016). Osa-aikatyö yksityisillä palvelualoilla. Raportteja 33. Palkansaajien tutkimuslaitos. Helsinki.

Kainulainen, V. (2020) Prekaari palvelutyö ja ammattiyhdistystoiminnan muutospaineet. Teoksessa J. Kantola, P. Koskinen Sandberg \& H. Ylöstalo (toim.) Tasa-arvopolitiikan suunnanmuutoksia: Talouskriisistä tasa-arvon kriiseihin. Helsinki: Gaudeamus.

Kainulainen, V. (2018). Työntekijöiden ääni ja tunteet matalapalkkaisen yksityisen sektorin luottamusmiestoiminnassa. Sosiologia (55)3, 263-280.

Kainulainen, V. \& Saari, M. (2014). "Nyrkkiä pöytään ja helmat paukkumaan? Luottamusmiestoiminnan sukupuolistavat käytännöt yksityisellä palvelusektorilla." Työelämän tutkimus (12)3, 211-226.

Kirton, G. (2006). Alternative and parallel career paths for women: the case of trade union participation. Work, employment and society (20)1, 47-65. DOI: 10.1177/0950017006061273.

Komulainen, K. \& Sinisalo, P. (2006). "Mul on amerikkalaisten työajattelumalli" Itsensä työllistävien naisten urakertomukset ja yrittäjäminä. Työelämän tutkimus (4)3, 149-159.

Korvajärvi, P. (2004). Sukupuolistavien käytäntöjen valta. Teoksessa P. Eriksson, J. Hearn, M. Jyrkinen, S. Meriläinen, J. Moisander, H. Niemi, K. Rolin, S. Vanhala, E. Henttonen, M. Hiillos, S. Katila \& T. Tallberg (toim.) Sukupuoli ja organisaatiot liikkeessä? Gender and Organisations in Flux? Helsinki: Forskningsrapporter från Svenska handelshögskolan. Swedish School of Economics and Business Administration Research Reports 60, 20-29. 
Korvajärvi, P. (2002). Gender-neutral Gender and Denial of Difference. Teoksessa B. Czarniawska, \& H. Höpfl (toim.) Casting the Other. London: Routledge, 119137. DOI: $10.4324 / 9780203994221$.

Korvajärvi P. \& Kinnunen M. (1996). Lopuksi: Työelämän sukupuolistaminen. Teoksessa M. Kinnunen ja P. Korvajärvi. (toim.) Työelämän sukupuolistavat käytännöt. Jyväskylä: Vastapaino, 233-240.

Lawrence, E. (1994). Gender and Trade Unions. London: Taylor \& Francis.

Ledwith, S. (2012). Gender politics in trade unions. The representation of women between exclusion and inclusion. Transfer: European Review of Labour and Research (18)2, 185-199. DOI: $10.1177 / 1024258912439145$.

Leinikki, S. (2009). Pelon ja toivon välissä: Pätkätyöläisen urakerronta. Akateeminen väitöskirja. Työelämäjulkaisut TJS Opintokeskus. Helsinki: Yliopistopaino.

Lindsay, C. (2005). 'McJobs', 'good jobs' and skills: jobseekers' attitudes to low-skilled service work. Human Resource Management Journal (15)2, 50-65. DOI: 10.1111/j.1748-8583.2005.tb00146.x.

Marcus, G. E. (1995). Ethnography in/of the World System: The Emergence of Multi-Sited Ethnography. Annual Review of Anthropology 24, 95-117. DOI: 10.1146/annurev.an.24.100195.000523.

Moore, S. (2011). New Trade Union Activism: Class Consciousness or Social Identity? Hampshire: Palgrave Macmillan. DOI: 10.1057/9780230294806.

Ott, Brian (2016). The Limits of Control in Service Work: Interactive Routines and Interactional Competence. Teoksessa Research in the Sociology of Work, Volume 29. Emerald Group Publishing Limited, 155-183. DOI: 10.1108/S0277-283320160000029022.

PAM (2019a). PAM pähkinänkuoressa. https://www.pam.fi/ tietoa-pamista/pam-pahkinankuoressa.html (5.6.2019).
PAM (2019b). PAMin toimitsijan henkilökohtainen tiedonanto 1.11.2019.

PAM (2019c). Henkilökuntahaku. https://www.pam.fi/ yhteystiedot/henkilokuntahaku.html (31.4.2019).

Rubery, J. \& Hebson, G. (2018). Applying a gender lens to employment relations: Revitalisation, resistance and risks. Journal of Industrial Relations (60)3, 414-436. DOI: 10.1177/0022185618766680.

Saari, M. (2016). Samapalkkaisuus - neuvoteltu oikeus: Naisten ja miesten palkkaeriarvoisuus poliittisena ja oikeudellisena kysymyksenä korporatistisessa Suomessa. Akateeminen väitöskirja. Valtiotieteellisen tiedekunnan julkaisuja.

SAK (2004). Edunvalvonnan arkea pienillä työpaikoilla. Tutkimustieto 2/2004. Helsinki.

Salmi, M. \& Lammi-Taskula, J. \& Mäntylä, E. (2016). Pienten lasten äidit osa-aikatyöhön? Politiikan ja käytäntöjen ristiriitoja. Yhteiskuntapolitiikka (8)2, 206-215.

Sullivan, S. \& Baruch Y. (2009) Advances in Career Theory and Research: A Critical Review and Agenda for Future Exploration. Journal of Management (35)6, 1542-1571. DOI: 10.1177/0149206309350082.

TEM (2015). Palvelutalouden murros ja digitalisaatio - Suomen kasvun mahdollisuudet. Työ- ja elinkeinoministeriön julkaisuja. Innovaatio. 12/2015.

Wajcman, J. (2000). Feminism Facing Industrial Relations in Britain. British Journal of Industrial Relations (38)2, 183-201. DOI: 10.1111/1467-8543.00158.

Wallin, A. (2007). Teoreettisia näkökulmia ammatilliseen kasvuun. http://www.awailable.com/ tiedostot/20070424_TEOREETTISIA_N_K_KULMIA_ AMMATILLISEEN_KASVUUN.pdf $(25.11 .2019)$. 